\title{
What is a New Zealand Journal of Educational Research for?
}

\author{
Georgina Stewart $^{1} \cdot$ Leon Benade $^{1} \cdot$ Nesta Devine $^{1}$
}

Published online: 3 November 2020

(c) New Zealand Association for Research in Education 2020

Tēnā koutou katoa. This is our sixth co-written editorial, with which we arrive at the end of our initial 3-year term as the Co-Editors and Book Reviews Editor of Te Hautaka Mātai Mātauranga, having overseen the last three volumes, 53-55 (20182020). We have gladly accepted a further 3 years editing the journal (2021-2023), but take this milestone as an opportunity to reconsider our role as its editors, by discussing the purpose of a New Zealand journal of educational research.

The history of the journal was recapitulated in an editorial written 5 years ago by our predecessors for the 50th volume, who noted that the journal's first issue in 1966 "contained six articles and five book reviews" (Bourke and Loveridge 2015, p. 1). Today, these remain our two main forms of publication, supplemented with occasional commentaries and research notes. On this observation "it could be argued that little has changed" (p. 1), but "the way issues are framed, and the language used" (p. 2) have changed significantly.

On its inauguration in 1966, the journal recorded "concern" with Māori education, but was written "from a dominant paradigm of privilege" whereby research sought the causes of "Māori educational retardation" (p. 2). Clearly, Māori education has been a central concern of the journal since its first volume, and remains so today. In this way, the journal documents the longstanding and ongoing importance of Māori education in the work of the New Zealand educational research community, and its transformation from the colonising 'education of Māori' to the critical, decolonising, Kaupapa Māori notion of 'education for Māori'.

One of our first achievements as new editors in 2018 was to correct the spelling of the Māori name of the journal, which for about 10 years, including the years of its transition to Springer, was published as 'Te Hautaki' instead of 'Te Hautaka'. Making this change as was no simple matter, since it required changes to the Springer website. How the premier New Zealand journal of educational research ended up being published for 10 years with a spelling mistake in its own name can be seen as a 'cautionary tale' for biculturalism in education in Aotearoa New Zealand.

Leon Benade

leon.w.benade@aut.ac.nz

Georgina Stewart

georgina.stewart@aut.ac.nz

1 Auckland University of Technology, Auckland, New Zealand 
The 1986 milestone of reaching 20 years of publication was celebrated by the journal editors of the time, David McKenzie and Ted Glynn, by inviting reflections on its future. Philip Lawrence lamented that NZJES "had not broadened its range of contributors, but rather had become 'a house journal for the publications of university lecturers in education"” (Bourke and Loveridge 2015, p. 2). Ivan Snook reflected that educationalists of the day still tended to associate with the parent disciplines (psychology, philosophy, etc.) rather than with each other, and recorded his wish to see academics in education "from a range of discipline backgrounds working together to inform policy and practice, to benefit policy makers and teachers alike" (Bourke and Loveridge 2015, p. 2). In 2020, contributors to the journal now include a wide range of academics, from postgraduate students to professors, based in New Zealand and overseas, across all sectors of education. The journal also receives some manuscripts researching educational concerns within other disciplines (business, health, etc.).

Today, NZJES is the official journal of the New Zealand Association for Research in Education (NZARE), viewed as the local equivalent of the Australian Education Researcher journal of the Australian Association for Research in Education (AARE), the British Education Research Journal of the British Education Research Association (BERA) in the UK, the Educational Researcher journal of the American Education Research Association (AERA) in the USA and Canada, and the European Education Research Journal for the European Education Research Assocation (EERA). NZJES is an important national forum for educational research and scholarship based in New Zealand universities, wānanga, and other tertiary and community research institutes, and, as noted above, is regarded as the premier journal of educational research located in or associated with this country. As such, the journal plays a complex role in the field of local educational scholarship, with overlapping aspects relating to the community, discipline, and politics of education.

Community: As a voice for the research community, the journal advocates on behalf of the education community of this country: the schools, teachers, students, and whānau, whose lives depend on the success of the educational initiatives considered in the pages of the journal. The journal connects the education community to the research community. The NZARE Council is responsible for major decisions about the journal, such as the appointment of editors and members of the editorial and international advisory board. The journal's primary readership are the members of NZARE, and it is a symbolic representation of that community and its interests.

One special category of publications in NZJES are the Herbison lectures; written forms of the named keynote speech that concludes the main programme of each NZARE annual conference (see www.nzare.org.nz/awards/herbison-lecture). In our tenure to date, we have received and published one Herbison lecture, delivered by Leonie Pihama at the 2017 conference held at University of Waikato (Pihama 2019). The publication of this particular lecture demonstrates the political nature of the work that editors of a journal such as NZJES are sometimes called upon to undertake.

Discipline: Like all academic journal editors, we are tasked with upholding editorial ethics and the disciplinary standards of 'research excellence' in managing the content of the issues under our supervision. In this imperative, we are 
representing our community of academic research in education, and the everchanging norms of published research in our field. In their first editorial, Bourke and Loveridge (2014) considered the nature of educational research as consisting of both 'new knowledge' and the applications of that knowledge to "inform change for educators, policy makers, teachers and other researchers" (p. 2), noting that "NZJES has always been an avenue for publishing the findings from both primary concerns" (p. 3).

Our role in the 'discipline' also operates in the other sense, since NZJES is a prime venue for local academics seeking to fulfil their minimum publication expectations for PBRF assessment, by which they are 'disciplined' every 6 years on their 'research outputs'. Behind the bright face of 'excellence' lurks the shadow image of the power exerted by research journals such as NZJES over individual academics, seeking to establish and advance their careers, and avoid being made redundant by downsizing.

As editors of a Springer journal, we are also held to account by the demands of an international publisher. Springer expects its journal editors to strive to improve their journal's metrics for article downloads, citations, and so forth; and to exercise agency by, for example, encouraging submissions from certain groups of international authors, mindful of the detailed processes of how journal metrics are calculated.

Politics: Education is a favourite 'political football' in our national politics, and is regularly called on to ameliorate a wide range of social ills. In Aotearoa New Zealand, the government is the major funder of education and educational research, so "the politics of research in education can be seen in what is funded, and not, and the priority given, or not, to particular research agendas" (Bourke and Loveridge 2014, p. 3). The above paragraphs show how NZJES occupies an important place in the specific political history and contemporary context of national education. We take seriously the journal's role in providing a venue for critical commentary on topical issues in education in Aotearoa New Zealand. As the editors of NZJES, we operate across these three intersecting domains, with their various, often conflicting, drivers and aims.

Two current events are likely to impact on the journal in the next few years. First, the 2020 pandemic response redefined the importance of key workers: health workers, supermarket workers, postal workers-and teachers. After 20+ years of denigration, our profession is being treated with more respect as parents and politicians find that teaching really is skilled work-and vital for the continued functioning of the economy. The journal can presumably look forward to celebrating and confirming a newfound respect for education and educators in the post-Covid-19 world. Second, the 2019 PBRF Review report is now available, and its recommendations include more capacious definitions of research excellence that more fairly recognise Māori and Pacific research, in overt attempts to widen participation in the process, whilst retaining "the individual as the unit of measurement" (PBRF Review Panel 2020, p. 8). Such signalled changes in the national research agenda will no doubt be reflected in the research to be published in future issues.

We thank all our authors, reviewers, and board members for their contributions to the journal over the last 3 years. We salute the readers, without whom the work of 
producing the journal would be in vain, and look forward to continuing our work for the journal over the next 3 years.

\section{References}

Bourke, R., \& Loveridge, J. (2014). The role of educational research. New Zealand Journal of Educational Studies, 49(1), 2-5.

Bourke, R., \& Loveridge, J. (2015). Fifty years! The New Zealand Journal of Education Studies (NZJES) Te Hautaki [sic] Mātai Mātauranga o Aotearoa 1966-2015. New Zealand Journal of Educational Studies, 50(1), 1-5.

PBRF Review Panel. (2020). E koekoe te tū̄, e ketekete te kākā, e kūkū te kererū. Retrieved from www. education.govt.nz/further-education/policies-and-strategies/review-of-the-performance-based-resea rch-fund.

Pihama, L. (2019). Colonisation, Neoliberalism and Māori Education: Herbison Invited Lecture, NZARE Annual Conference 2017. New Zealand Journal of Educational Studies, 54(1), 5-19.

Publisher's Note Springer Nature remains neutral with regard to jurisdictional claims in published maps and institutional affiliations. 